\title{
Attitudes and local ecological knowledge of experts fishermen in relation to conservation and bycatch of sea turtles (reptilia: testudines), Southern Bahia, Brazil
}

Heitor de Oliveira Braga ${ }^{1 *}$ and Alexandre Schiavetti ${ }^{1,2}$

\begin{abstract}
Background: The use of ethnoecological tools to evaluate possible damage and loss of biodiversity related to the populations of species under some degree of threat may represent a first step towards integrating the political management of natural resources and conservation strategies. From this perspective, this study investigates fishermen's ecological knowledge about sea turtles and attitudes towards the conservation and bycatch in Ilhéus, Southern Bahia, Brazil.

Methods: Fishermen experts semi-structured interviews were performed using snowball sampling method. The interviews consisted of a series of questions relating to the fishermen's profile, structure and work equipment, the local ecological knowledge of fishermen about sea turtles and bycatch, a projective test, attitudes towards turtle conservation and beliefs and taboos regarding turtles. Indicators for quantitative comparisons of respondents in terms of their broad knowledge and attitudes towards turtle conservation were created. Correlation analyses were made between indicators of knowledge and attitude as well as the relationship between education level and knowledge and attitudes.

Results: Thirty experts were interviewed for the study. The local ecological knowledge and attitudes of fishermen towards the conservation of sea turtles were respectively medium (0.43) and moderate (0.69) according to experts (based on Likert scale and Cronbach's Alpha). Potential areas of spawning were reported from Barra Grande to Una covering the entire coast of Ilhéus. Methods for identifying the animal, behavior, and popular names were described by fishermen. The most recent captures of turtles were attributed to fishing line, but according to the respondents, lobster nets and shrimp traps are more likely to capture turtles. Knowledge and attitudes were weakly inversely correlated $(r=-0.38, p=0.04)$, and the education level of the respondent showed a positive correlation with positive attitudes towards turtle conservation $(H=8.33 ; \mathrm{p}=0.04)$. Life history, habitat, specific and exogenous taboos, beliefs and the use of hawksbill turtle to make glasses and other handcrafts are also reported in the study.

Conclusions: Monitoring of spawning areas, preservation of traditional practices, strategies to moderate the use of fishery resources and the local ecological knowledge/attitudes can provide data to improve the conservation practices and management of sea turtles.
\end{abstract}

Keywords: Marine turtle, Marine conservation, Taboos

\footnotetext{
* Correspondence: heitorob@gmail.com

'Programa de Pós-Graduação em Ecologia e Conservação da Biodiversidade, Universidade Estadual de Santa Cruz - UESC, Rodovia Jorge Amado km16, Ilhéus, Brazil

Full list of author information is available at the end of the article
} 


\section{Background}

Sea turtles are susceptible to damage through various interactions with humans, due to the fact that they are migratory and occupy distinct geographical areas according to their stage of life $[1,2]$. On a global scale, all species of sea turtles in Brazil are under some level of threat according to the International Union for the Conservation of Nature (IUCN) [3], including the green turtle (Chelonia mydas) and loggerhead turtle (Caretta caretta), which are threatened with extinction; the olive turtle (Lepidochelys olivacea), which is vulnerable to extinction; and the leatherback turtle (Dermochelys coriacea) and hawksbill turtles (Eretmochelys imbricata), which are critically endangered species.

An assessment of the conservation status of turtles in Brazil performed by the Chico Mendes Institute for Biodiversity Conservation (ICMBio)/TAMAR (Sea turtles) Project, reported the green turtle C. mydas as vulnerable (VU), C. caretta and L. olivacea as in danger (EM) and E. imbricata and D. coriacea as critically endangered $(\mathrm{CR})$, which indicates reductions in the populations of these taxa in recent years on the Brazilian coast [4-8].

There are several threats that these animals face in the sea or on the beaches where they nest $[9,10]$. Human activities and impacts such as vehicular traffic on beaches, plastic pollution, contamination with oil, the spreading of pathogens, the accidental capture of turtles by fishermen, the gathering of eggs and females on beaches, global climate changes, collisions of turtles with boats and the dredging of harbours and channels can be cited as the primary causes of the declines in turtle populations on a global scale [11-13]. In particular, turtle strandings may also be considered a major threat to the populations of these animals in coastal areas [14].

Most importantly, according to Epperly et al. [15] and Cheng and Chen [16], the greatest impact on the survival of these animals is the use of fishing equipment, with emphasis on the fishing nets that are recognized as a major factor in the mortality of sea turtles across the world [17]. In Brazil, the homemade devices are commonly used on the coast [18]. Studies of the artisanal fisheries in Brazil are still few and there are no accurate statistics on such activity $[19,20]$, representing a significant gap with regard to information on the bycatch of sea turtles [21].

Studies investigating the attitudes of members of traditional communities regarding the conservation of a particular resource can have great importance for the preservation of the ecosystem [22]. Furthermore, information derived from the community members' knowledge of the environment can assist in management and co-management efforts, contribute to the existing knowledge of the biology of various organisms and their interactions with the environment [23] and provide important data to help shape the decisions of policymakers and researchers [24,25].

Most of the interactions between humans and their environment are known to be mediated by feelings, behaviors, knowledge and beliefs [26]. Understanding and comprehension of the bio-cultural memory associated with the local knowledge of a particular traditional community as well as efforts to represent those community members and collaborate with their existence [27] are increasingly being utilized and incorporated in the responses to environmental and social changes [28].

The use of ethnoecological tools, like interviews and projective test, to evaluate possible damage and loss of biodiversity related to the populations of species under some degree of threat may represent a first step towards integrating the political management of natural resources and conservation strategies with the behavior of the local community so that fishery resources can be utilised rationally, with a consequent decrease in the mortality of sea turtles. From this perspective, this study investigates fishermen's local ecological knowledge about sea turtles and attitudes towards the conservation and bycatch of sea turtles (Reptilia: Testudines) in Ilhéus, Southern Bahia, Brazil.

\section{Methods}

\section{Study site}

The present study was conducted in the municipality of

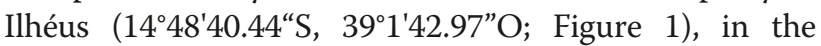
southern region of the state of Bahia, Brazil. This area has a population of 180,000 inhabitants and an area of $1841 \mathrm{~km}^{2}$ [29]. The climate of the region, according to the Köppen classification scheme, is Af; warm and humid tropical, without a predictable dry season and with an average annual rainfall of $2000 \mathrm{~mm}$ [30].

The coastal region of Ilhéus is $80 \mathrm{~km}$ long and almost straight with few protrusions or recesses, bounded by the Sargi river to the north, the Acuípe river to the extreme south, and by the continental shelf, the edge of which passes between the $50 \mathrm{~m}$ and $60 \mathrm{~m}$ isobaths [31,32]. The hydrography of the region consists of two basins: the Cachoeira and the Almada. These basins are part of most of the routes of the fishermen of Ilhéus. There are two colonies of fisherman in Ilhéus: Z-19 and Z-34. These were chosen for use in this study because of the ease of finding fishermen to facilitate data collection. Located on the edge of Pontal Bay, colony Z-19 was founded in 1921 and is currently managed by José Leonardo Oliveira dos Santos. It comprises 3,000 members, of whom only 700 are active fishermen. Colony Z-34, located in the Malhado neighborhood, was founded in 1947, is currently managed by José Reynaldo Oliveira, and has approximately 3,000 active members, including individuals from neighboring municipalities 


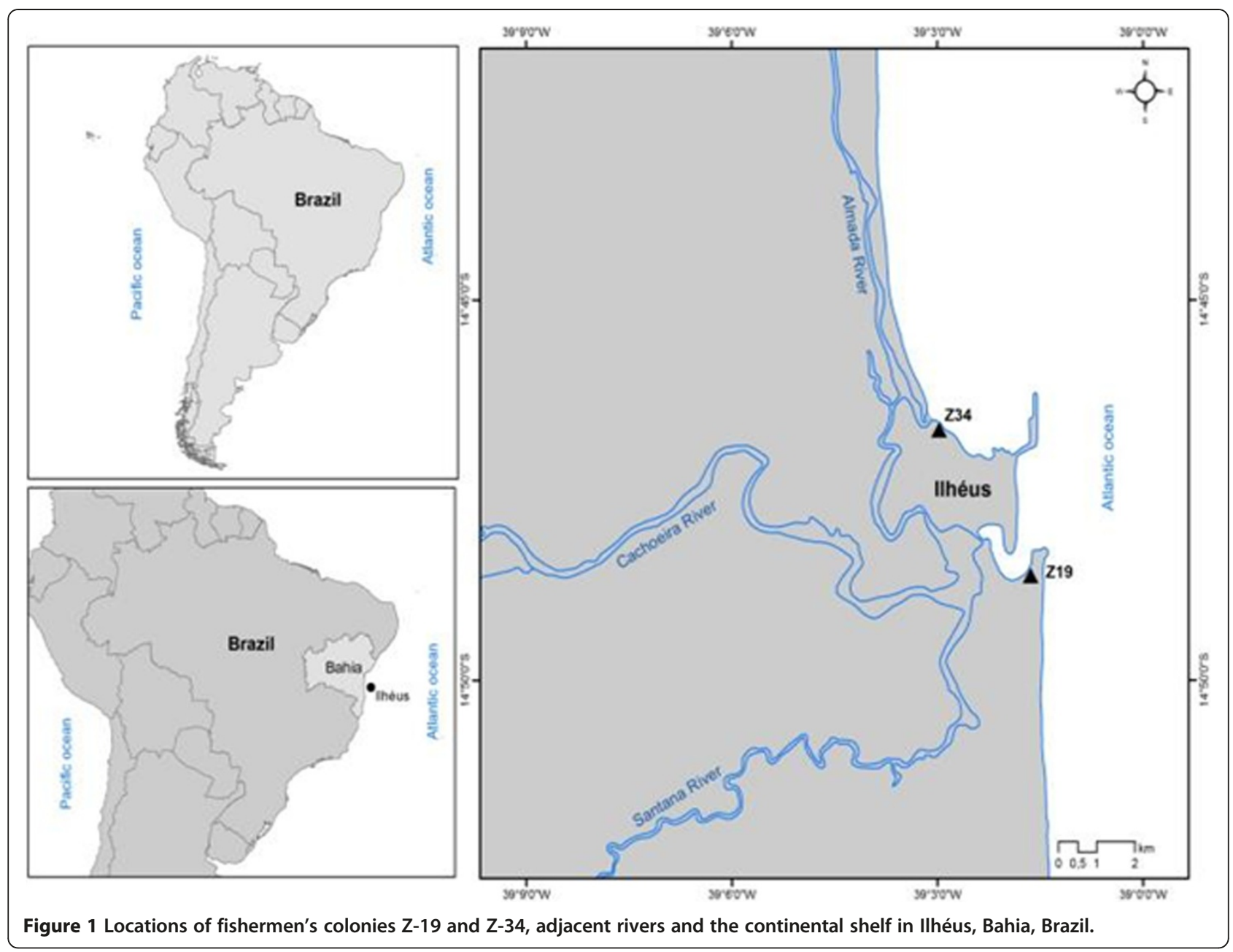

[32]. These two colonies of fishermen are organs of the working class artisanal fisheries sector, legal form and with themselves in the city of Ilhéus, Bahia, Brazil.

\section{Procedures}

Data collection took place from July 2010 to September 2011 in colonies Z-19 and Z-34. Interviews were conducted with experts fishermen. These fishermen were sampled using the method snowball method [33] in which fishermen in a particular locality indicate that people have greater knowledge and field experience among all fishermen. This sampling method was modified and adapted [34], where experts fishermen were selected through the initial indication by the president of the fishing colony. Field data were collected first through semi-structured interviews [35] and later through welldesigned questionnaires which are suitable for research where it is desired to quantify the results subsequently [36]. The schedule of interviews to fishermen was adapted according to the forecasted arrival of the fishing boats, where we expected the best time for them to grant the interview. Constant contact with the research subject is observed as a necessary investment in studies of local ecological knowledge according to Brook [37].

Initially, the names of three fishermen who had relevant knowledge about fishing in Ilhéus were collected from the presidents of each colony using the criterion "native expert(s)", meaning individuals who are selfacknowledged or recognized by the community as experts and persons that have a long history of fishing in the area $[33,38,39]$. The selected expert fishermen each indicated three additional fishermen and so forth, constituting an indication network (Figure 2). The network terminated when a fisherman was cited more than once. A fisherman was considered an expert if he was indicated two or more times. The fisherman experts were interviewed after being identified through the formation of the indication network. The interviews consisted of a series of questions (Table 1) relating to the fishermen's profile, structure and work equipment, the local ecological knowledge (LEK) of fishermen about sea turtles and bycatch of sea turtles (It was considered local ecological knowledge of the fisherman on the ecology of the sea turtle and animal behavior), a projective test 
[40], attitudes towards turtle conservation (This part of the interview was assessed by the awareness of the respondent regarding the conservation status of turtles and their tendency to have positive action in relation to maintenance of the population of turtles) and beliefs and taboos regarding turtles (It was considered food preferences and aversions of fishermen and their implications for conservation of sea turtles). The projective test was performed by presenting six sea turtle species to record the perceptions and knowledge of respondents. To avoid skewing the test, the turtle Lepidochelys kempii (Kemps Ridley or Lora) was not used in the questionnaire due to its similarity to Lepidochelys olivacea (Olive), which is recorded in Brazil. Interviews were recorded on paper. We considered the common names of all species of sea turtles to assess knowledge through projective test. The questionnaire was pre-tested using a pilot study conducted in colony Z-18 in Itacaré, Bahia. Ten interviews were conducted in the pilot study. This procedure helped to adapt the questionnaire before applying it [41].

The fishermen were approached individually, with some interference from other fishermen present at the interview site. Despite this interference, the only responses recorded were those provided by the individual who was being interviewed. At the start of all interviews, the fishermen received a document entitled "Statement of Informed Consent (IC)" and agreed to participate in the research.

The interviews covered the emic approach with respect to the point of view of the research subjects [42]. The taboos were classified into the following categories (life history, temporal, habitat, specific, segmental, method) proposed by Colding and Folke [43] and the classification of fishing gear was based upon the "International Standard Statistical Classification of Fishing Gear" (ISSCFG) [44].

For quantitative comparisons of the respondents in terms of their broad knowledge and attitudes towards the conservation of turtles, indicators were created based on the study by Nazario and Bitencourt [45]. Data were converted using a three-point Likert scale for both knowledge (correct answers $=1$, partial answers $=0.5$, wrong answers $=0$ ) and attitudes (positive attitudes $=1$, moderate attitudes $=0.5$, negative attitudes $=0$ ). This scale quantifies the attitudes of individuals based on an order of numerical qualificative importance, expressing agreement or disagreement with respect to variables and attitudes related to the study object [46]. The indicators for local ecological knowledge and attitudes towards conservation were created by summing the scores for each subject and dividing the total by the highest possible score [45-47]. The reliability and internal consistency of these indicators was measured by Cronbach's alpha coefficient, which assesses the magnitude to which the items in a group are correlated $[48,49]$. Knowledge and attitude indicators were divided into three classes (0-0.33; 0.34 - 0.66; 0.67 - 1). Attitudes were classified as positive, moderate and negative, whereas knowledge was classified as low, medium and high (based on Likert scale and Cronbach's Alpha).

Correlation analyses were made between indicators of knowledge and attitude, investigating the relationship

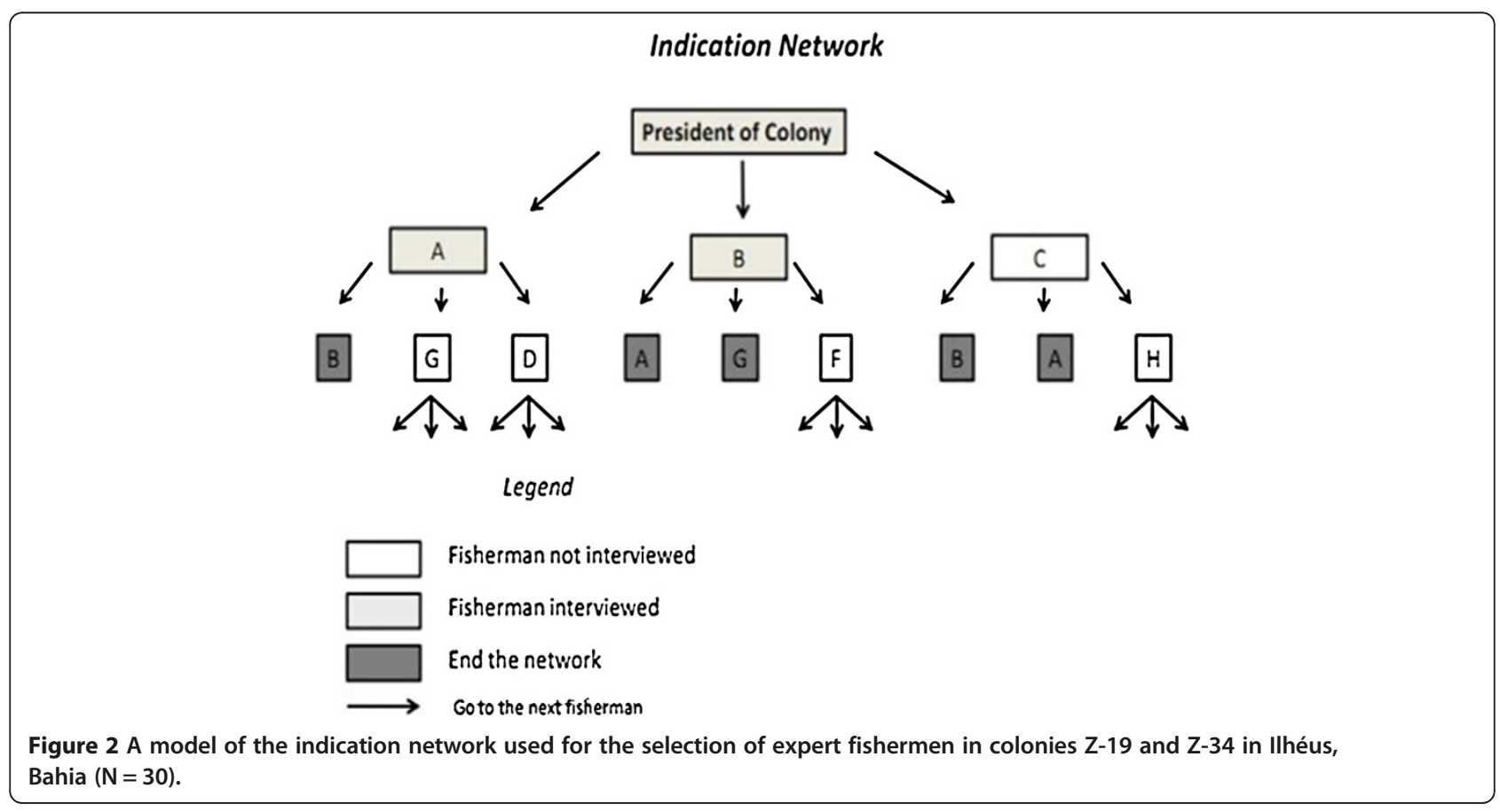


Table 1 Characteristics of questionnaire applied to the fishermen experts in Ilheus, Bahia, Brazil, 2010-2011

\begin{tabular}{lcc}
\hline Characteristics & Number of questions & Percentage of questionnaires \\
\hline Fisherman profile (sex, age, birthplace, no of children, schooling) & 10 & 12 \\
Structure and work equipment (types of fishing boat, fishing activity) & 19 & 23 \\
Knowledge about turtles (feeding areas/nesting areas/dive time/ecological knowledge) & 13 & 16 \\
Projective test (identification of species of turtles through images/photos) & 6 & 7 \\
Knowledge bycatch (depth, capture location, likely species, state animal, fishing gear). & 16 & 20 \\
Attitudes towards conservation (probable reactions around turtles) & 8 & 10 \\
Beliefs and Taboos (eat, when, who can?) & 10 & 12 \\
Total & 82 & 100 \\
\hline
\end{tabular}

between profile variables of the respondent (time associated with the fishing colony, age and number of children) and knowledge and attitudes as well as the relationship between education level and knowledge and attitudes. We investigated the relationship between indicators and level of education by classifying education level as follows: $\mathrm{A}=$ illiterate; $\mathrm{B}=$ Elementary School 1 (1-5 years); C = Elementary School 2 (6-9 years) and $\mathrm{D}=$ Secondary school and Higher Education. KruskalWallis $(\mathrm{H})$ non-parametric tests, correlation analyses $(\mathrm{r})$ and Cronbach's alpha coefficient $(\alpha)$ were conducted using $\mathrm{R}$ version 2.12.1. The ltm package for $\mathrm{R}$ was used to calculate Cronbach's alpha coefficient $(\alpha)$ [50].

\section{Results}

\section{Profile of the fishermen}

The indication network of colony Z-19 included 34 fishermen. Of these, 21 were considered experts. The network of colony Z-34 included 26 fishermen, of which only 13 were considered experts. Thirty experts were interviewed for the study. Only 4 experts refused to participate in the work.

The ages of the respondents ranged from 40 to 86 years, and they were all male. The average fishing experience was 32 years, and the majority of respondents had a low level of education (Table 2). We interviewed 7 illiterate fishermen and 3 who had completed high school. The time associated with the fishing colony varied from 3 to 52 years with a mean of 24 years, and $87 \%$ of respondents lived only on their fishing income. The predominant types of fishing boat in Ilhéus were fiber and wood, and fishing trips averaged 4 crew members. The boats were generally small (4-6 m width; 7-14 m length), $66 \%$ of the experts used the boats of other fishermen and the fishing gear most often used was fishing line and trawl nets. The average frequency of fishing trips was three to four times per month. The time at sea per fishing trip varied with the type of fishing gear used (trawl nets $=10-20$ days; line $=7-8$ days).

\section{Local ecological knowledge about sea turtles}

The indicator of local ecological knowledge about sea turtles as measured by the Likert scale ranged from 0.26 to 0.77 with an average value of 0.43 . In general, the local ecological knowledge about sea turtles was average. None of the candidates obtained the minimum or maximum values of the indicator. According to the established classes, $27 \%$ of the fishermen had a low level of knowledge about sea turtles, $63 \%$ had medium knowledge and $10 \%$ had a high level of knowledge. The Cronbach's alpha coefficient for knowledge was approximately 0.7 . The index of knowledge was not associated with the age of the fishermen $(r=0.10$, $\mathrm{p}=0.62$ ), the number of children of the fishermen $(\mathrm{r}=0.08, \mathrm{p}=0.66)$ or the time associated with the fishing colony $(\mathrm{r}=-0.05, \mathrm{p}=0.80)$.

All fishermen said they had seen turtles along the coast of Ilhéus. The experts cited 20 nesting areas from Barra Grande to Una covering the entire coast of Ilhéus. Of these, Olivença and Ponta do Ramo were most frequently cited by experts as nesting areas for sea turtles (6-7 times). Ponta da Tulha and Acuípe were also remembered as spawning areas (4-5 times) and the remainder were cited by at least one respondent (1-3

Table 2 Profile of the experts interviewed in the colonies of fishermen Ilhéus, Bahia ( $\mathrm{N}=30-100 \%$ male)

\begin{tabular}{|c|c|c|c|c|}
\hline & $\%$ & Minimum & Mean & Maximum \\
\hline Age (years) & & 40 & 54 & 86 \\
\hline Schooling (years) & & 0 & 5 & 14 \\
\hline Fishing time(years) & & 13 & 32 & 60 \\
\hline T associated the colony(years) & & 3 & 24 & 52 \\
\hline Time of residence in Ilhéus(years) & & 10 & 41 & 63 \\
\hline No of children & & 1 & 3 & 7 \\
\hline \multicolumn{5}{|l|}{ Occupation: } \\
\hline Fishing only & 87 & & & \\
\hline Others & 13 & & & \\
\hline
\end{tabular}


times, Figure 3). In relation to nesting areas, all fishermen said that turtles spawn on desert beaches, and 38\% said that spawning occurs mostly in the summer.

In the projective test, only one fisherman mentioned that Natator depressus occurs in the region. All others cited at least one species that occurs on the coast of Bahia. Of the experts interviewed, $45 \%$ correctly identified the species E. imbricata; 24\%, C. mydas; 10\%, C. caretta; (being all respondents belonging to the classes of medium or high knowledge) and $13 \%, D$. coriacea (only one respondent belonged to the class of low knowledge and the rest belonging to the other two classes). No fisherman identified the species L. olivacea. Most experts identified the turtles based on their shell, colour, size and fins. It is important to note the record of $D$. coriacea made by a fisherman interviewed in the south of Ilhéus, specifically on the high seas in front of Comandatuba Island. This fisherman was one of the four respondents who recognized the leatherback turtle and described some details consistent with the literature.

The interviewed experts identified the various types of turtle by their common names, referring to $C$. mydas as the green turtle, suranha and aruanã. The species E. imbricata was identified as the hawksbill turtle and as malhada. $C$. caretta was identified as the common and the yellow turtle. D. coriacea was identified as the leathery, skin, and black turtle and as Jamanta. L. olivacea and $N$. depressus were not identified by the fishermen by their common names.

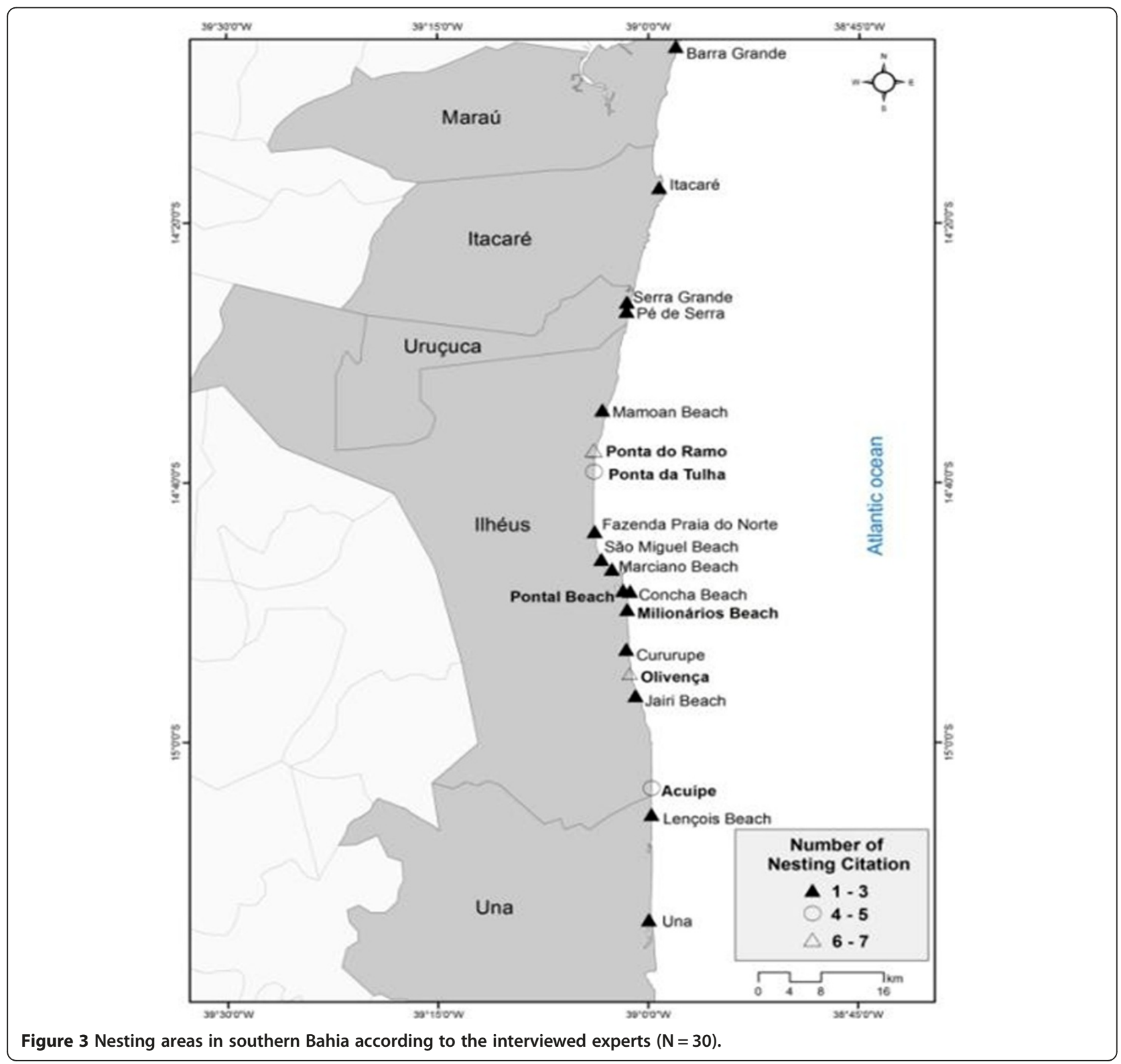


When asked to identify turtle foods, all experts cited at least one type of food correctly according to literature [51-53] and when asked about the predators of turtles, they cited men, sharks, some birds (albatrosses and black vultures) and fish (goliath grouper, common dolphinfish and shark). Responses provided regarding the turtles' dive time varied significantly between respondents and $53 \%$ mentioned a correct time interval with reference to some studies [54-56]. According to the fishermen, the preferred habitats of the turtles are places with rocks, reefs, beaches and shallow and deep water. The fishermen reported that the turtles' diet consists of seaweed, small fish, crustaceans, limestone, shellfish and shrimp. Plastics and several wastes were also cited as parts of their diet. Although the overall level of knowledge was medium, some fishermen showed satisfactory knowledge compared with the literature on the ecology and behavior with regard to the chelonians studied.

\section{Knowledge about bycatch}

Only 1 expert had never accidentally caught a turtle during a fishing operation. During each respondent's last reported capture, $66 \%$ were using fishing line as their fishing gear and $94 \%$ of the captured turtles were alive and in a normal state without apparent injury. Their average weight was $31 \mathrm{~kg}$ and depth was $36 \mathrm{~m}$ at the last sighting. The coasts of Ilhéus, Olivença and Acuípe were cited as the localities with the highest numbers of records for turtle captures. In the interviews, most of the fishermen attributed their most recent turtle capture to fishing line, but all experts said that the fishing gear that picks up the most turtles in the region of Ilhéus is the nets (gill/lobster, $\mathrm{n}=27$; shrimp trawl, $\mathrm{n}=2$ ) and that turtles are rarely captured by lines (fund, submerged or half water; $n=1)$ or long-lines $(n=1)$.

\section{Attitudes towards conservation}

The indicator for attitudes towards conservation of sea turtles had an average value of 0.69 . The study participants proved to be alerted before the causes of the decline of sea turtle population, tending to present awareness and actions more accurate than negative that can assist in the recovery of the conservation status of the species studied. This ranged from 0.35 to 1 and only 2 fishermen obtained the maximum value. Most of the interviewees (59\%) had positive attitudes the maintenance of the sea turtles population in the study region and the other $41 \%$ held moderate attitudes. No negative attitudes were recorded. The Cronbach's alpha index calculated for attitudes was 0.43 . The index of attitudes was not correlated with time associated with the fishing colony $(\mathrm{r}=-0.18, \mathrm{p}=0.35)$, the respondent's age $(\mathrm{r}=-0.28$, $\mathrm{p}$-value $=0.15)$ or the respondent's number of children $(\mathrm{r}=-0.04, \mathrm{p}=0.83)$.
Ninety percent of respondents thought it was important to conserve turtles and the environment where they live. Ninety-seven percent did not think that sea turtles affect fishing, but only $47 \%$ knew how to explain this fact. Only one interviewee did not approve of the law that has prohibited the capture and use of sea turtles in Brazil since 1986 (Decree of SUDEPE, paragraph 005 of January 31, 1986, IBAMA 2009) along with other complementary legislation. Seventy-three percent of the experts had previously held unfavorable attitudes related to the consumption of sea turtle eggs, but all said that they no longer consumed the eggs in the present.

In a hypothetical encounter with a turtle, 3 fishermen said that they would consume it or use the shell for making hand-crafted products. When asked about how to avoid catching turtles, $27 \%$ said that they did not know how and 73\% said that they avoid using fishing nets (shrimp and lobster) to avoid catching turtles catch.

\section{Local ecological knowledge and attitudes towards conservation}

In the present work, there was a tendency for attitudes towards turtles to be inversely related to knowledge about sea turtles. The correlation between these two indicators was negative and significant $(\mathrm{r}=-0.38, \mathrm{p}=0.04)$. The interviewed experts who exhibited a greater local ecological knowledge about sea turtles tended to have more unfavorable attitudes towards the conservation of chelonians (Figure 4).

\section{Relationship between level of education and the indicators}

In this study, the fishermen's level of education did not influence the extent of their local ecological knowledge about sea turtles $(\mathrm{H}=1.27 ; \mathrm{p}=1.74)$. Regarding attitudes towards conservation, there was a tendency for more highly educated fishermen to have more positive attitudes towards turtle conservation $(\mathrm{H}=8.33$; $\mathrm{p}=0.04 ;$ Figure 5).

\section{Beliefs and taboos}

In the study of the perceptions of the fishing communities of Ilhéus, sea turtles were mentioned as taboo by $48 \%$ of the interviewed experts. They were considered taboo as food due to their "strong" meat, for presenting leathery shell, and have the ability to cause disease when ingested. The turtles were locally referred to as "remoso" and "carregado". The folk medicine of some of the fishermen included uses for sea turtles (21\%). Therapeutic indications for human use that were mentioned by the experts included the use of turtle lard oil as a remedy for rheumatism, muscle aches, fatigue and back pain and for fighting bronchitis and asthma. 


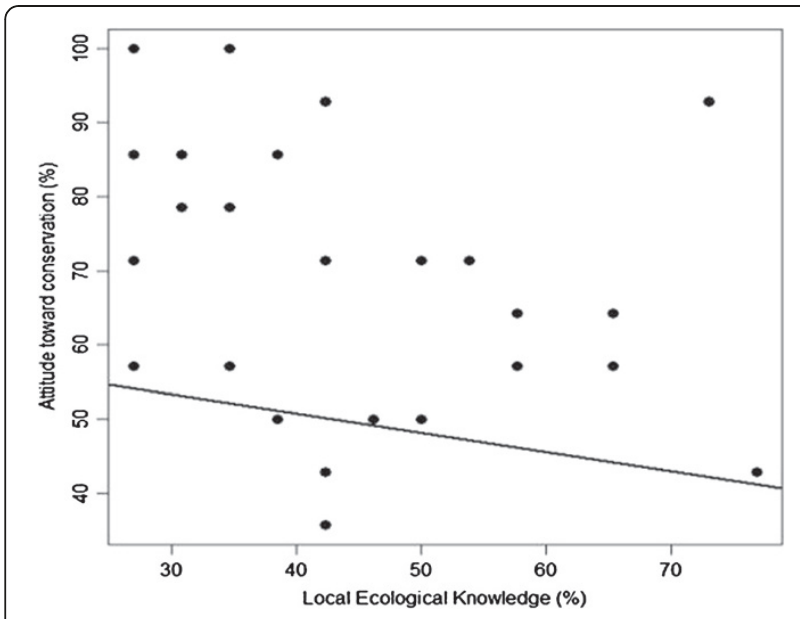

Figure 4 The correlation between local ecological knowledge about sea turtles and attitudes towards their conservation $(p=0.04, N=30)$.

Specific taboos were recorded for situations in which individuals had dietary restrictions defined in relation to sea turtles. The situations comprised the following: postoperative periods for both sexes, some types of inflammation, chronic disease and pregnancy in women. Of the interviewed experts, 4 said that they did not consume turtles with external characteristics such as the presence of warts and lumps on the body of the animal or the presence of a jellyfish on the face. The justification was that consuming turtles with these characteristics may harm a person's health.

Life history taboos were also observed, in which $45 \%$ of respondents said that they only eat adult and elderly turtles and restrict their use of the species at early stages

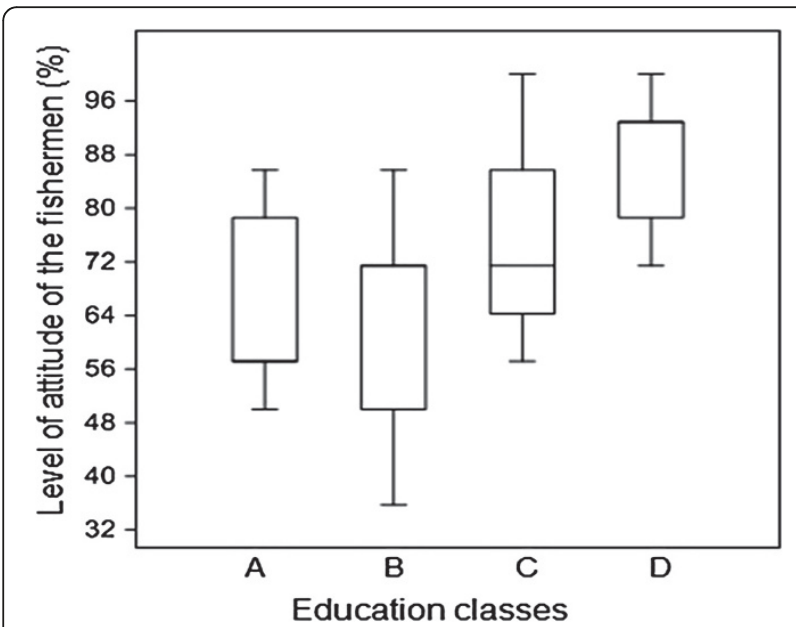

Figure $\mathbf{5}$ The correlation between the level of favourable attitudes of the fisherman towards conservation (\%) and education categories $(A=$ illiterate, $B=$ Elementary School 1, $C=$ Elementary School 2, D = Secondary school and higher, $\mathrm{N}=30$ ). of its development (young). Habitat taboos were also recorded for $24 \%$ of respondents. According to the interviewees, there are places where fishing access is limited due to the presence of turtles. Fishermen cited the following locations: Pé de Serra, Ponta do Espigão, Pedra de Ilhéus and Abrolhos as places where they avoid fishing because of the large number of turtles found in these areas.

Among the 4 experts who said they have used the shells of sea turtles, primarily hawksbill turtles, to make glasses and other handcrafts, there was no food restrictions related to the consumption of eggs. The fishermen do not use the meat for commercial purposes. When a turtle is captured, they consume it at sea or take the meat home. Fifty-two percent of the respondents enjoy turtle meat compared to beef and chicken.

\section{Discussion}

\section{Knowledge about sea turtles}

Keeping in mind that the survey was conducted only with fishermen experts who had been recognized as knowledgeable about fishing in the region, one can say that we recorded as much information as possible and that no other local fishermen had different or deeper knowledge than what we recorded. The index we generated to measure local ecological knowledge presented an acceptable degree of reliability. According to Gabriel and Tritapepe [57], values of Cronbach's alpha above 0.6 are considered satisfactory for opinion polls. The local ecological knowledge about sea turtles according to the Likert scale was predominantly medium and high, which was expected due to the long fishing trips, which helps to increase the probability of encounters with animals. Regarding indicator individually, no fisherman got full or zero knowledge about the animal, which was expected, because most fishermen have already reported some contact with turtle at sea or on the beaches, which helps to generate information habitat, breeding and feeding sites and nesting.

It was assumed that the fishermen who were identified by the indication networks in the two colonies had a deeper knowledge of turtles. This assumption may be incorrect considering that fishing effort is directed towards species of fish and laws are currently in place in Brazil that restrict fishing for turtles, with the result that fishermen's contact with turtles is only casual. Most of the fishermen experts we interviewed also use a bottom line, which is considered a type of fishing gear that is less likely to catch turtles compared with other types of gear [58]. Calo et al. [32] concluded that the fishermen of the same study area possess considerable knowledge about snapper fish (Actinopterygii: Teleostei) "vermelhos", a group of large fish, knowledge which was possibly acquired by exploiting the fish with fishing gear, an activity which does not occur with the sea turtle. 
Sea turtles are considered key species in coral reef communities [53,59]. Many interviewed fishermen reported avoiding fishing in areas where there is a greater probability of interaction with the animal. Decree No. 037 regulating Municipal Law No. 3212 of 01/30/ 2006 was completed in 2011 for the realization of the creation of Municipal Marine Park Ilhéus to protect some marine species, with an emphasis on Epinephelus itajara (the goliath grouper). Even while under construction, the existence of this initiative may explain the avoidance of this type of ecosystem by fishermen in the region, which in the future may have a positive effect on the population growth of sea turtles in the region. However, the regulations imposed on fishermen to reduce fishing should always be constantly monitored and revised because the survival of individuals in fishing areas may often depend on the attitudes of the fisherman, who in a given time can be influenced negatively, especially when there is an initial assessment appropriate to the likely impacts to coastal communities [17]. Another reason for the low capture rate of turtles is that contact between fishermen and the animal may cause a decrease in fishing effort, generating financial and material losses, even if minimal. Marcovaldi et al. [60] report that fishing-animal interactions can cause damage to the fishing target. Nevertheless, the fact that many interviewees said that turtles do not affect their fishing is not for the simple reason that turtles do not cause any equipment damage or reduction in effective fishing time, but because they have only occasional contact with turtles and consequently the probability of damage caused by turtles is low. This fact can also be a reflection of the continued work of the Tamar as in many parts of the Brazilian coast, through which many anglers may have absorbed a more conservationist discourse that is not necessarily (but can be) a reflection of realities in their day-to-day.

Despite the finding that the fishermen's local ecological knowledge about sea turtles as communicated through interviews was not within the range that represents deep knowledge, the interviews with experts did identify areas of great importance for nesting turtles. In these sub-areas of Ilhéus on the southern coast of Bahia, there are records of strandings of four species of sea turtles [14]. The increased recognition of hawksbill turtles in the projective test can be explained by the fact that hawksbill species have been recorded nesting on the southern coast of Bahia [61] relation to the projective still some limitations methodology as shown figures (drawings and pictures two-dimensional), the color variation of the hull according to the animal immersion in water may have been implicated in the recognition species.

In the municipalities of Itacaré and Uruçuca, there are reports of turtle nests on the beaches of Pompilho, Itacarezinho and Patizeiro [62]. Due to the hawksbill turtle's peculiarities, for decades products have been extracted from the animals for export and sale to tourists [63]. Among all species, the hawksbill turtle is the one that has suffered the greater depredation as a result of its shell [64]. The hawksbill turtle's shell holds more use than those of other species, and their greater contact with fishermen may have influenced the collaboration and greater recognition on the part of respondents.

There are few studies in the literature that address the history of the leatherback turtle in the state of Bahia. The current conservation status of the species is "in critical condition" [3,5]. There are sporadic reports of spawning in the extreme south of Bahia [65], and the shore in the state of Espírito do Santo is cited as the most important nesting area for this species in Brazil [66], with a population that is genetically differentiated from the rest of the country [67]. In the present study, some fishermen were able to identify the leatherback turtle, even if they had only fished in southern Bahia throughout their lives. Huntington [36] emphasizes the importance of incorporating this type of local ecological knowledge into research projects and management strategies and of integrating, analyzing and incorporating this new knowledge. Thus, this type of initial information can be an important step for the conservation of potential new nesting areas of the species in southern Bahia, where studies on population structure and nest monitoring are nonexistent.

Even with a few catches to the bottom line in the study area, fishermen warned of the impact of the use of net fishing in the region. Trawling for lobster and the use of fishing nets have been identified as one of the main threats to sea turtle populations worldwide $[12,17,68,69]$. In Brazil, the impact of lobster trawling in Bahia has already been observed [70]. These methods can drive large decreases in sea turtle populations because forced apnea may further aggravate the state of captured turtles, which can lead to death [71].

Attitudes towards conservation and their relationship with other variables - The low Cronbach's alpha value suggests that the items analyzed express different attributes and cannot be jointly adopted in the calculation of a one-dimensional variable [45]. For Pereira [58], there is a stipulated amount of alpha needed to determine the validity of an indicator. Values above 0.40 have been satisfactory for some studies [47,72].

Fishermen experts demonstrated predominantly positive attitudes. Coastal communities with nesting areas in Sri Lanka exhibited similar attitudes [73]. The influence of community attitudes towards conservation in traditional and some demographic variables has been almost nonexistent $[74,75]$. Negative attitudes were provided by fishermen with a greater number of children because it is expected that a family with a large number of members requires a 
greater amount of food energy for their sustenance. In Boer and Baquete [76] also found no relationship between number of children and attitudes around an elephant reserve in Mozambique. Even with environmental education activities and occasional lectures given to members of the local community, no trend was identified between attitudes and time associated with the fishing colony. As was observed in the fishing community in this study, the age of the respondents did not influence attitudes in two protected areas in Nepal [77]. Mehta and Keller [78] also documented the same trend. Thus, the profile variables of the respondents recorded in this study did not influence the attitudes of the respondents in relation to the conservation of sea turtles in the region of Ilhéus.

More unfavorable attitudes towards the conservation of sea turtles were held by those fishermen who know more about their behavior and could best distinguish their habitat characteristics. It is expected that foraging and capture of turtles are easier for those fishermen who have a more enhanced level of knowledge about the resource. Bright and Tarrant [79] reported that knowledge increases the ability to think, looking at all sides of the issue, but does not always influence the direction of the attitudes of an individual. In this case, the above knowledge about the rules of endangered species in the United States did not influence the perceptions and attitudes of students.

These unwritten social rules can be a way to conserve a resource. Fiallo and Jacobson [80] found the same relationship between these two variables. Positive attitudes were exhibited by those with a higher level of education, perhaps because the access to the information acquired during their studies, access to different types of media and greater contact with educated people could help in better assimilating the importance and need for conservation of resources that are threatened with depletion. According to Sah and Heinen [81], attitudes towards the conservation of a resource are influenced by educational level. However, there were some fishermen with low education levels who had positive attitudes towards the conservation of sea turtles. The fear of fines and punishments meted to those who violate environmental laws [47] may help explain this finding. The attitudes of these fishermen may also be influenced by some kind local belief. Bright and Barro [82] showed that beliefs can have influence over the attitudes of an individual in relation to natural resources in addition to just their knowledge.

\section{Beliefs and taboos}

Food taboos may be considered informal institutions that define and limit the use of resources by human communities in ecosystems, accounting for rules that are not instituted but somehow regulate human behavior [83]. In this study, the presence of food taboos can be considered a reason for the low consumption of sea turtles by fishermen of the macro-region of Ilhéus. These unwritten social rules can be a way to conserve a resource $[23,70]$. However, a decrease in adherence to traditional practices over time can cause a greater impact on some populations of animals and plants [84].

The specific taboos that were identified by interviewing experts of the two fishing colonies of Ilhéus are similar to those reported in studies from the Atlantic Forest and the Amazon [85,86]. Decreases in the exploitation of wild species can be aided by specific taboos [43]. Dietary restrictions related to the appearance and taste of meat was considered more a means of avoiding the consumption of the animal. The reasons attributed to the taboos by the fishermen were the same as those given by other fishermen in coastal communities in the southeast [85].

Exogenous taboos, in which laws are imposed on the population leading to a breakdown of the interaction between people and animals [87], may in some cases assist in the conservation of a resource. Often, this kind of taboo cannot control all of the actions of the fishermen, as occurs in the fishing community of Ilhéus. The chelonians, especially sea turtles and turtles, are one of the most popular ingredients used in traditional medicine around the world [88]. In northeastern Brazil there are several records of the use of animals and plants in alternative therapies [89].

In Bahia, turtles are known to be highly utilized in zootherapy and alternative medicine [90] as well as in communities in the southeast of São Paulo [85,91] and in Rio Tocantins [86]. In the region of this study as well as in other traditional communities, turtle fat is used for the treatment of asthma, bronchitis and arthritis [85,92]. On the north coast of Bahia as well as on the coast of Ilhéus in southern Bahia, fat is only used in this way when there is bycatch [87].

\section{Conservation concerns}

Among the species of sea turtles that are recorded in Brazil, all are under some degree of threat [3-7]. The use of bycatch in nets by traditional coastal communities is a major factor in the declining populations of turtles [93].

In relation to fisheries, lobster and shrimp trawling should be adapted and restricted in certain ecosystems due to the high probability of turtle capture. Fishing colonies should always be involved in any change in fishing regulations, and participation in key decisions should be interactive. Despite the fact that this type of fishing is not considered a major contributor to the problem of bycatch worldwide, this type of fishing should still be constantly monitored due to its large magnitude and its ability to generate deep local environmental effects [94].

Data acquired from local ecological knowledge can assist in strategies and programs for sustainable conservation and management policies [24] and generate important discussions to strengthen the understanding of the 
resource under study [95]. The preservation of traditional practices such as sustainable food taboos, beliefs and customs is necessary. In relation to the sustainable use of resources in zootherapies, there must be a local analysis and a thorough observation of the possible implications of the practice, as well as a check for immediate needs to provide appropriate management measures as it relates to the conservation of the species [89].

An individual with a higher knowledge rating did not have more positive attitudes towards turtles in our study. However, mitigation measures related to environmental education should not be discarded, but should be reviewed and explored in a more appropriate way. Recommendations are needed for effective communication strategies in cases where there is a propensity towards negative attitudes by fishermen with a greater degree of knowledge about the ecology of the animal. Even in the generally positive attitudes that prevail among the interviewed experts, there are still fishermen who occasionally use turtles which can be detrimental to the species, especially females who are more coastal and more likely to be predation.

Studies monitoring the nests, clutches and local ecological knowledge of sea turtles in southern Bahia are needed due to the scarcity of data in the existing scientific literature, especially for the leatherback and hawksbill turtles, which need urgent help because of their critical conservation status. Strategic conservation and mitigation measures must be developed and applied so that a significant portion of the existing diversity of turtles is not lost over the coming centuries [96].

The involvement of the community in conservation activities and monitoring may, over the long term, contributes to increased knowledge and more favorable attitudes [97]. Promoting beliefs and taboos conducive to sea turtles conservation could foster positive attitudes and behavior.

\section{Conclusions}

Due to the series of threats that this population group is confronting animal comes into the world, ethnoecological studies are recommended for areas where gaps exist regarding the population structure and conservation status of marine turtles as identified in this study.

According to experts fishermen in Southern Bahia, the incidental capture of sea turtles is occurring, these being mainly attributed to fishing line, because most fishers use this fishing gear with main instrument of fishing. However, respondents acknowledged the fishing nets as major factor of mortality of sea turtles in southern Bahia.

Traditional knowledge about the biology of the animal was evidenced, analyzed and compared with the scientific literature on zoology and biology of the animal was a series of confirmations of such knowledge.

\section{Competing interests}

The authors declare that they have no competing interests.

\section{Authors' contributions}

$\mathrm{HOB}$ and $\mathrm{AS}$ - Writing of the manuscript, literature survey and interpretation; HOB - Collected, organized and analysis data; AS - Contributed with ideas on the study and discussion, involved in revising the manuscript. All authors read and approved the final manuscript.

\section{Acknowledgements}

A MSc fellowship from CNPq was granted to $\mathrm{H}$. Braga and a Productivity fellowship was granted to Dr. Alexandre Schiavetti. Logistical facilities during field work were provided by PPGECB UESC and Projeto TAMAR/ICMBio. Special thanks to the researchers, MSc. Henrique Matheus Farias de Oliveira and Dr. Mauricio Moreau who collaborated to produce this work. We also wish to recognize the fishermen communities for their willingness to participate in the interview and collaborate with the notes of the fishing books. Thanks to Rodrigo Hueb by collaboration.

\section{Author details}

${ }^{1}$ Programa de Pós-Graduação em Ecologia e Conservação da Biodiversidade, Universidade Estadual de Santa Cruz - UESC, Rodovia Jorge Amado km16, Ilhéus, Brazil. ²Departamento de Ciências Agrárias e Ambientais (DCAA), Universidade Estadual de Santa Cruz - UESC, Rodovia Jorge Amado km16, Ilhéus, Bahia, Brazil.

Received: 12 October 2012 Accepted: 26 February 2013 Published: 1 March 2013

\section{References}

1. Plotkin PT, Spotila JR: Post-nesting migrations of loggerhead turtles caretta caretta from Georgia, USA: conservation implications for a genetically distinct subpopulation. Oryx 2002, 36:396-399.

2. Godley BJ, Lima EHSM, Åkesson S, Broderick AC, Glen F, Godfrey MH, Luschi $P$. Hays GC: Movement patterns of green turtles in Brazilian coastal waters described by satellite tracking and flipper tagging. Mar Ecol Prog Ser 2003, 253:279-288.

3. IUCN: International Union for Conservation of nature: IUCN Red list of threatened species. http://www.iucn.org/about/work/programmes/species/ our_work/the_iucn_red_list/.

4. Almeida AP, Santos AJB, Thomé JCA, Belini C, Baptistotte C, Marcovaldi MA Santos ASS, Lopez M: Avaliação do estado de conservação da tartaruga marinha chelonia mydas (linnaeus, 1758) no Brasil. Biodiversidade Brasileira 2011, 1:12-19.

5. Almeida AP, Thomé JCA, Baptistotte C, Marcovaldi MA, Santos AS, Lopez M: Avaliação do estado de conservação da tartaruga marinha dermochelys coriacea (vandelli, 1761) no Brasil. Biodiversidade Brasileira 2001, 1:37-44.

6. Marcovaldi MA, Lopez GG, Soares LS, Santos AJB, Bellini C, Santos AS, Lopez M: Avaliação do estado de conservação da tartaruga marinha eretmochelys imbricata (linnaeus, 1766) no Brasil. Biodiversidade Brasileira 2011, 1:20-27.

7. Castilhos JC, Coelho CA, Argolo JF, Santos EAP, Marcovaldi MA, Santos AS, Lopez M: Avaliação do estado de conservação da tartaruga marinha lepidochelys olivacea (eschscholtz, 1829) no Brasil. Biodiversidade Brasileira 2011, 1:28-36.

8. Santos AS, Soares LS, Marcovaldi MA, Monteiro DS, Giffoni B, Almeida AP: Avaliação do estado de conservação da tartaruga marinha caretta caretta (linnaeus, 1758) no brasil. Biodiversidade Brasileira 2011, 1:3-11.

9. Marcovaldi MA, Thomé JCA: Reducing threats to turtles. In Research and Manegement Techniques for the conservation of sea turtles. Edited by Eckert KL, Bjorndal KA, Abreu-Grobois FA, Donnelly M. Washington, D.C.: Blanchard; 1999:165-168.

10. Tisdell C, Wilson C: Do open-cycle hatcheries relying on tourism conserve sea turtles? Sri Lankan developments and economic-ecological considerations. Environ Manage 2005, 35:441-452.

11. National Research Council (US): Decline of the sea turtles: causes and prevention. Washington: National Academy Press; 1990.

12. Shanker K, Pilcher NJ: Marine turtle conservation in south and southeast Asia: hopeless cause or cause for hope? Mar Turt News/2003, 100:43-51. 
13. Mast RB, Hutchinson BJ, Howgate E, Pilcher NJ: MTSG update: IUCN/SSC marine turtle specialist group hosts the second burning issues assessment workshop. Mar Turt News/ 2005, 110:13-15.

14. Coelho BB: Análise dos encalhes de tartarugas-marinhas (reptilia: testudines), ocorridos no litoral sul da bahia, brasil. Universidade Estadual de Santa Cruz: Tese de mestrado da; 2009.

15. Epperly SP, Braun J, Chester AJ, Cross FA, Merriner JV, Tester PA, Churchill $\mathrm{JH}$ : Beach strandings as an indicator of at-sea mortality of sea turtles. Marine Science 1996, 59:289-297.

16. Cheng I-J, Chen T: The incidental capture of five species of sea turtles by coastal setnet fisheries in the eastern waters of Taiwan. Biol Conserv 1997, 82:235-239.

17. Casale P, Laurent L, De Metrio G: Incidental capture of marine turtles by the Italian trawl fishery in the north Adriatic Sea. Biol Conserv 2004, 119:287-295.

18. MPA: Ministério da Pesca e Aqüicultura: O diagnóstico da pesca extrativa no Brasil.. http://www.mpa.gov.br/index.php/101-apresentacao/250-odiagnostico-da-pesca-extrativa-no-brasil.

19. Bertozzi CP: Interação com a pesca: implicações na conservação da toninha, pontoporia blainvillei (cetacea, pontoporiidae) no litoral do estado de São Paulo, SP. Universidade de São Paulo: Tese de doutorado da; 2009.

20. Souto FJB: O bosque de mangues e a pesca artesanal no distrito de acupe (Santo Amaro, Bahia): uma abordagem etnoecológica. Acta Scientiarum Biological Sciences 2008, 30:275-282.

21. Pupo MM, Soto JMR, Hanazaki N: Captura incidental de tartarugas marinhas na pesca artesanal da Ilha de Santa Catarina, SC. Biotemas 2006, 4:63-72

22. Alexander SE: Resident attitudes towards conservation and black howler monkeys in Belize: the community baboon sanctuary. Environ Conserv 2000, 27:341-350.

23. Begossi A, Hanazaki N, Silvano RAM: Ecologia humana, etnoecologia e conservação. In Métodos de coleta e análise de dados em etnobiologia etnoecologia e disciplinas correlatas. Anais do I seminário de etnobiologia e etnoecologia do sudeste. Edited by Amorozo MCM, Ming LC, Silva SP. Rio Claro SP: Unesp/CNPq; 2002:92-128.

24. Stave J, Oba G, Nordal I, Stenseth NC: Traditional ecological knowledge of a riverine forest in Turkana, Kenya: implications for research and management. Biodivers Conserv 2007, 16:1471-1489.

25. Brook RK, McLachlan SM: Trends and prospects for local knowledge in ecological and conservation research and monitoring. Biodivers Conserv 2008, 17:3501-3512

26. Marques JGW: Pescando pescadores. Ciência e etnociência em uma perspectiva ecológica. 2nd edition. São Paulo, Brazil: NUPAUB-USP; 2001.

27. Toledo VM, Barrera-Bassols N: Etnobiologia e etnoecologia - pessoas \& natureza na américa latina. In A etnoecologia: uma ciência pós-normal que estuda as sabedorias tradicionais. Edited by Silva VA, Almeida ALSA. Albuquerque UP: Recife: Nupeea; 2010:13-36.

28. Davis A, Wagner J: Who knows? On the importance of identifying "experts" when researching local ecological knowledge. Hum Ecol 2003, 31:463-489

29. IBGE: Instituto Brasileiro de Geografia e Estatística: Censo demográfico 2000-2010. http://www.ibge.gov.br/home/estatistica/populacao/censo2010/ tabelas_pdf/total_populacao_bahia.pdf.

30. Mori SA, Boom BB, Carvalho AM, Santos TS: Southern Bahia moist forests. Bot Rev 1983, 49:155-232.

31. França AMC: Geomorfologia da Margem Continental Leste Brasileira e das Bacias Oceânica Adjacentes. In Margem Continental Brasileira e das Áreas Oceânicas Adjacentes, vol. 7. Edited by Chaves H. Petrobras, Rio de Janeiro: A. F., Projeto REMAC; 1979:89-127.

32. Caló CFF, Schiavetti A, Cetra M: Local ecological and taxonomic knowledge of snapper fish (teleostei: actinopterygii) held by fishermen in Ilhéus, Bahia, Brazil. Neotropical Ichthyology 2009, 7:403-414.

33. Bailey KD: Methods of social research. New York: The Free Press, Macmillan Publishers; 1982

34. Biernacki $P$, Waldorf $D$ : Snowball sampling: problems and techniques of chain referral sampling. Sociological Methods \& Research 1981, 10(2):141-163.

35. Viertler RB: Métodos antropológicos como ferramenta para estudos em etnobiologia e etnoecologia. In Métodos de coleta e análise de dados em etnobiologia, etnoecologia e disciplinas correlatas anais do I encontro de etnobiologia e etnoecologia do sudeste. Edited by Amorozo MCM, Ming LC, Silva SMP. Rio Claro: CACB/Unesp-CNPq; 2002:11-29.
36. Huntington HP: Using traditional ecological knowledge in science: methods and applications. Ecol App/ 2000, 10:1270-1274.

37. Brook RK: Elk-agriculture conflicts in the greater riding mountain ecosystem: building bridges between the natural and social sciences to promote sustainability. University of Manitoba, Winnipeg, Manitoba, Canada: Dissertation; 2007.

38. Marques JGW: Pescando pescadores: etnoecologia abrangente no baixo São Francisco. São Paulo, Brazil: NUPAUB-USP: 1995

39. Alarcon DT: Interações entre cetáceos e atividades pesqueiras na área proposta para reserva extrativista marinha de itacaré (BA). Universidade Estadual de Santa Cruz: Tese de mestrado da; 2006.

40. Costa-Neto EM, Santos-Fita D, Clavijo M: Manual de etnozoología: Una guía teórico-práctica para investigar la interconexión del ser humano con los animales. Valencia, Spain: Tundra Ediciones; 2009:285.

41. White PCL, Jennings NV, Renwick AR, Barker NHL: Review: questionnaires in ecology: a review of past use and recommendations for best practice. J Appl Ecol 2005, 42:421-430.

42. Posey DA: Etnobiologia: teoria e prática. In Suma etnológica brasileira. Edited by Ribeiro D. Petrópolis, RJ: Vozes/FINEP; 1986:15-28

43. Colding J, Folke C: Taboo system: lessons about informal institutions for nature management. The Georgetown International Environmental Review 2000, 12:413-445.

44. FAO: Food and Agriculture Organization of the United Nations: Fisheries and aquaculture department nations - fishing gear type.. http://www.fao.org/ fishery/geartype/search/en.

45. Nazario N, Bittencourt MD: Atitudes e condutas de produtores rurais perspectivas de conservação dos remanescentes de cerrado do assentamento reunidas, promissão - SP. OLAM - Ciência \& Tecnologia 2003, 3:309-350.

46. Dencker AFM: Métodos e técnicas de pesquisa em turismo. São Paulo, Brazil: Futura; 1998:286.

47. Ditt EH: Fragmentos florestais no pontal do paranapanema. São Paulo, Brazil: Annablume; 2002:140.

48. Pereira JCR: Análise de dados qualitativos: estratégias metodológicas para as ciências da saúde, humanas e sociais. São Paulo, Brazil: USP; 1999:154.

49. Oviedo HC, Campo-Arias A: Metodología de investigación y lectura crítica de estudios: aproximación al uso del coeficiente alfa de cronbach. Revista Colombiana de Psiquiatria 2005, 34:572-580.

50. Rizopoulos D: Itm: an R package for latent variable modeling and item response theory analyses. J Stat Softw 2006, 17:1-25.

51. Bjorndal KA: Foraging ecology and nutrition of sea turtles. In The biology of Sea turtle. Edited by Lutz PL, Musick JA. Boca Raton: CRC Press; 1997:199-231.

52. Sanches TM, Bellini C: Juvenile eretmochelys imbricata and chelonia mydas in the archipelago of Fernando de Noronha, brazil. Chelonian Conservation and Biology 1999, 3:308-311.

53. León YM, Bjorndal KA: Selective feeding in the hawksbill turtle, an important predator in coral reef ecosystems. Mar Ecol Prog Ser 2002, 245:249-258.

54. Godley BJ, Richardson S, Broderick AC, Coyne MS, Glen F, Hays GC: Longterm satellite telemetry of the movements and habitat utilization by green turtles in the Mediterranean. Ecography 2002, 25:352-362.

55. Bentivegna F, Hochscheid S, Minucci C: Seasonal variability in voluntary dive duration of the Mediterranean loggerhead turtle, caretta caretta. Sci Mar 2003, 67:371-375.

56. Hays GC, Houghton JDR, Isaacs C, King RS, Lloyd C, Lovell P: First records of oceanic dive profiles for leatherback turtles, dermochelys coriacea, indicate behavioral plasticity associated with long-distance migration. Anim Behav 2004, 67:733-743.

57. Gabriel MLDS, Tritapepe PRS: Análise da motivação de compra do consumidor de instrumentos musicais da Rua teodoro sampaio. 1998. http://www.ead.fea. usp.br/semead/10semead/sistema/resultado/trabalhosPDF/199.pdf.

58. Projeto Tamar - ICMBio: National Sea turtle conservation in brazi. http://www.icmbio.gov.br/portal/images/stories/docs-plano-de-acao/pantartarugas/livro_tartarugas.pdf.

59. Bjorndal KA, Bolten AB: From ghosts to key species: restoring sea turtle populations to fulfi II their ecological roles. Mar Turt News/ 2003, 100:16-21.

60. Marcovaldi MA, Thomé JCA, Sales G, Coelho CA, Gallo BMG, Bellini C: Brazilian plan for reduction of incidental sea turtle capture in fisheries. Mar Turt Newsl 2002, 96:24-25.

61. Marcovaldi MA, Marcovaldi GG: Marine turtles of brazil: the history and structure of projeto TAMAR-IBAMA. Biol Conserv 1999, 91:35-41. 
62. Cammilo CS, Romero RM, Leone LG, Batista RLG, Velozo RS, Nogueira-Filho SLG: Características da reprodução de tartarugas marinhas (Testudines, Cheloniidae) no litoral Sul da Bahia, Brasil. Biota Neotropica 2009, 9:1-7.

63. Hughes GR: The survival situation of the hawksbill sea-turtle (eretmochelys imbricata) in Madagascar. Biol Conserv 1973, 5:114-118.

64. Meylan $A B$, Donnelly M: Status justification for listining the hawksbil turtle (eretmochelys imbricata) as critically endangered on the 1996 IUCN Red list of threatened animals. Chelonian Conservation Biology 1999 3:200-224.

65. Marcovaldi MA, Sales G, Thomé JCA, Silva ACCD, Gallo BMG, Lima EHSM, Lima EP, Bellini C: Sea turtles and fishery interactions in brazil: identifying and mitigating potential conflicts. Mar Turt News/ 2006, 112:4-8.

66. Soto JMR, Beheregaray RCP, Rebello RARP: Range extension: nesting by dermochelys and caretta in southern brazil. Mar Turt News/ 1997, 77:6-7.

67. Vargas SM, Araújo FCF, Monteiro DS, Estima SC, Almeida AP, Soares LS, Santos FR: Genetic diversity and origin of leatherback turtles (dermochelys coriacea) from the Brazilian coast. J Hered 2008, 99:215-220.

68. Poiner IR, Harris ANM: Incidental capture, direct mortality and delayed mortality of sea turtles in Australia's northern prawn fishery. Mar Biol 1996, 125:813-825

69. Wallace BP, DiMatteo AD, Bolten AB, Chaloupka MY, Hutchinson BJ, AbreuGrobois FA, Mortimer JA, Seminoff JA, Amorocho D, Bjorndal KA, Bourjea J, Bowen BW, Briseño Dueñas R, Casale P, Choudhury BC, Costa A, Dutton PH, Fallabrino A, Finkbeiner EM, Girard A, Girondot M, Hamann M, Hurley BJ, López-Mendilaharsu M, Marcovaldi MA, Musick JA, Nel R, Pilcher NJ, Troëng $\mathrm{S}$, Witherington $\mathrm{B}$, Mast R: Global conservation priorities for marine turtles. PLoS One 2011, 6:1-14.

70. Reichel-Dolmatoff $\mathrm{G}$ : Cosmology as ecological analysis: a view from the rain forest. New series 1976, 11:307-318.

71. Lutcavage ME, Lutz PL: Diving physiology. In The biology of Sea turtles. Edited by Lutz PL, Musick JA. Boca Raton: CRC Press; 1990:277-296.

72. Drews C: Attitude, knowledge and wild animals as pets in Costa Rica. Society 2002, 15:119-138

73. Rajakaruna RS, Dissanayake DMNJ, Ekanayake EML, Ranawana KB: Sea turtle conservation in Sri Lanka: assessment of knowledge, attitude and prevalence of consumptive use of turtle products among coastal communities. Indian Ocean Turtle newsletter 2009, 10:1.

74. Hill CM: Conflicting attitudes towards elephants around the budongo forest reserve Uganda. Environmental Conservation 1998, 25:244-250.

75. Allendorf T, Swe KK, Oo T, Htut Y, Aung M, Allendorf K, Hayek L, Leimgruber $P$, Wemmer C: Community attitudes toward three protected areas in upper Myanmar (Burma). Environ Conserv 2006, 33:344-352.

76. Boer WF, Baquete DS: Natural resource use, crop damage and attitudes of rural people in the vicinity of the Maputo elephant reserve Mozambique. Environ Conserv 1998, 25:208-218.

77. Baral N, Heinen JT: Resources use, conservation attitudes, management intervention and park-people relations in the Western Terai landscape of Nepal. Environ Conserv 2007, 34:1-9

78. Mehta JN, Kellert SR: Local attitudes toward community-based conservation policy and programmes in Nepal: a case study in the makalu-barun conservation area. Environ Conserv 1998, 25:320-333.

79. Bright AD, Tarrant MA: Effect of environment-based coursework on the nature of attitudes toward the endangered species Act. J Environ Educ 2002, 33:10-19.

80. Fiallo EA, Jacobson SK: Local communities and protected areas: attitudes of rural residents towards conservation and machalilla national park, Ecuador. Environ Conserv 1995, 22:241-249.

81. Sah JP, Heinen JT: Wetland resource use and conservation attitudes among indigenous and migrant peoples in Ghodaghodi Lake are Nepal. Environ Conserv 2002, 28:345-356

82. Bright AD, Barro SC: Integrative complexity and attitudes: a case study of plant and wildlife species protection. Hum Dimens Wildl 2000, 5:30-47.

83. Colding J, Folke C: 1997: The relations among threatened species, their protection, and taboos. Conserv Ecol 1997, 1:6.

84. Pinto EPP, Amorozo MCM, Furlan A: Conhecimento popular sobre plantas medicinais em comunidades rurais de mata atlântica-itacaré, BA, Brasil. Acta Botanica Brasilica 2006, 20:751-762.

85. Begossi A: Food taboos at búzios island (brazil): their significance and relation to folk medicine. J Ethnobio/ 1992, 12:117-139.

86. Begossi A, Braga FM: Food taboos and folk medicine among fishermen from the Tocantins river (Brazil). Amazoniana 1992, 12:101-118.
87. Costa-Neto EM: Restrições e preferências alimentares em comunidades de pescadores do município de conde, estado da bahia, brasil. Rev Nutr 2000, 13:117-126.

88. Alves RRN, Vieira WLS, Santana GG: Reptiles used in traditional folk medicine: conservation implications. Biodivers Conserv 2008, 17:2037-2049.

89. Ferreira FS, Brito SV, Ribeiro SC, Saraiva AF, Almeida WO, Alves RRN: Animalbased folk remedies sold in public markets in crato and Juazeiro do Norte, Ceará Brazil. BMC complementary and alternative medicine 2009, 9:17.

90. Begossi A, Hanazaki N, Ramos RM: Food chain and the reasons for fish food taboos among Amazonian and Atlantic forest fishers (Brazil). Ecol Appl 2004, 14:1334-1343.

91. Alinõ PM, Cajipe GJB, Ganzon-Fortes ET, Licuanan WRH, Montano NE, Tupas LM: The use of marine organisms in folk medicine and horticulture: a preliminary study. In SICEN Leaflet 1: SUPplement of SICEN Newsletter University of the Philippines. Diliman, Quezon City, Philippines: Seaweed Information Centre (SICEN); 1990:298.

92. Seixas CS, Begossi A: Ethnozoology of fishing communities from tha Grande (Atlantic forest coast, Brazil). J Ethnobiol 2001, 21:107-135.

93. Marcovaldi MA, Giffoni BB, Becker $\mathrm{JH}$, Fiedler FN: Sea turtle interactions in coastal Net fisheries in Brazil. In Proceedings of the technical workshop on mitigating Sea turtle bycatch in coastal Net fisheries. IUCN: Regional Fishery Management Council; 2009:28.

94. Mclellan E, Arps E, Donnelly M: WWF Global Marine Turtle Strategy 2009-2020. Gland, Switzerland: WWF; 2009:44

95. Turner NJ, Ignace MB, Ignace R: Traditional ecological knowledge and wisdom of aboriginal peoples in British Columbia. Ecol Appl 2000 10:1275-1287.

96. Buhlmann KA, Akre TSB, Iverson JB, Karapatakis D, Mittermeier RA, Georges A, Rhodin AGJ, Vand Dijik PP, Gibbons JW: A global analysis of tortoise and freshwater turtle distributions with identification of priority conservation areas. Chelonian Conservation and Biology 2009, 8:116-149.

97. Brewer C: Outreach and partnerships programs for conservation education where endangered species conservation and research occur. Conserv Biol 2002, 16:4-6

doi:10.1186/1746-4269-9-15

Cite this article as: Braga and Schiavetti: Attitudes and local ecological knowledge of experts fishermen in relation to conservation and bycatch of sea turtles (reptilia: testudines), Southern Bahia, Brazil. Journal of Ethnobiology and Ethnomedicine 2013 9:15.

\section{Submit your next manuscript to BioMed Central and take full advantage of:}

- Convenient online submission

- Thorough peer review

- No space constraints or color figure charges

- Immediate publication on acceptance

- Inclusion in PubMed, CAS, Scopus and Google Scholar

- Research which is freely available for redistribution

Submit your manuscript at www.biomedcentral.com/submit
C) Biomed Central 